\title{
Survey Assessment of Indigenous Knowledge Systems for Seed Storage of Rainforest Spice (Monodora myristica) in Southeastern Nigeria.
}

\author{
Peter-Onoh, C. A., Onoh, P. A., Obiefuna, J. C., Ofor, M. O., Ngwuta, A. A., \\ Ibeawuchi, I. I., Korie, C. O., Orji, J. O., Agomuo, C. I., and Onoh, A. L. \\ School of Agriculture and Agricultural Technology, Federal University of Technology, Owerri Imo State.
}

\begin{abstract}
The assessment of indigenous knowledge for the storage of Monodora myristica seed for planting was carried out in three states (Abia, Enugu and Akwa-Ibom states) of South eastern agroecology. A structured questionnaire was administered to 150 farmers from two LGAs each and 135 retrieved. Data collected were subjected to descriptive statistics like percentage, mean scores, frequency, bar and pie chart. Collection/gathering of M. myristica is mostly done by men between the ages of 61-70\%. Those involved in gathering of M. myristica seeds were married and formally educated people. The study further revealed that traditional method of storage is widely accepted since it promotes seed germination as investigated by $74 \%$ of the respondents. Insect pest is one of the problems encountered by the farmers hence $66.7 \%$ of the respondents have solicited for government assistance. This problem should therefore be addressed as seed security is essential in ensuring increased use of agro-biodiversity which would in turn expand the options, opportunities and remains available at the rural grassroots level to improve nutrition and health, safeguard the household economic security and enhance sustainable agriculture.
\end{abstract}

Keywords: Indigenous knowledge, Monodora myristica, respondents, seed, , storage,

\section{Introduction}

Monodora myristica (African nutmeg) belongs to the family Annonaceae plants. The tree can reach a height of $35 \mathrm{~m}$ and $2 \mathrm{~m}$ in diameter at breast height and are found in the wild. The fruit is a berry of $20 \mathrm{~cm}$ diameter and is smooth, green and spherical and becomes woody at maturity. It is attached to a long stalk which is up to $60 \mathrm{~cm}$ long. Inside the fruit the numerous oblongoid, pale brown, $1.5 \mathrm{~cm}$ long seeds are surrounded by a whitish fragrant pulp. The odour and taste of the M. myristica seed is similar to nutmeg and it is used as a popular spice in the West African cuisine [1]. Spices are plant products used in flavouring foods and beverages [2]. It has nutritional value and often referred to as food accessories or adjuncts because of their ability to stimulate appetite and increase the flow of gastric juice [3]. The essential oils and terpenoid alcohol of spices contribute to their smell, taste and tactile sensation, that mostly spicy herbs have traditional medicinal values.

1.1

Concept of Indigenuos Knowledge Systems

Indigenous knowledge (IK) is the local knowledge - knowledge that is unique to a given culture or society [4]. It is based on experience, often tested over centuries of use and entails many insights, perceptions and intuitions relating to local culture and environment [5]. It is the basis for local-level decision making in agriculture, health care, food preparation, education, natural-resource management, and a host of other activities in rural communities. [6]. According to [ 7] sharing knowledge with the poor is most effective when we also solicit knowledge from them about their needs and circumstances. Therefore, development activities, especially those that aim to benefit the poor directly, need to consider IK in the design and implementation stages of the process.

Storage of seeds as ex situ germplasm is an essential step for the long-term conservation of plant genetic resources. Maintaining seed viability in store for longer period is very essential to preserve the genetic integrity as well as the physiological state for use.

The importance and demand of this spice in food and medicine, call for improvement in traditional storage methods and systems. Traditionally, farmers save and store seeds for two purposes, consumption and cultivation. In seeds for consumption, quality conservation is the priority while in seeds for cultivation viability is the primary concern. Quite often unviable seeds serve the alternative purposes of human food, livestock feed or manure. This paper surveyed and investigated the socio economic characteristic of indigenous knowledge systems for Monodora myristica seed storage skewed to seed storage for cultivation in Southeastern Nigeria. 


\section{Materials And Methods}

The study was carried out in three states (Abia, Enugu, Akwa Ibom) of southeast agroecological zone of Nigeria, which is characterized by coastal plains [8], and located within latitude $4^{0} 15^{\prime} \mathrm{N}$ and $7^{0} \mathrm{~N}$ and longitude $5^{\circ} 50^{\prime} \mathrm{E}$ and $9^{0} 30^{\prime} \mathrm{E}$. The entire southeast is about $7581126 \mathrm{ha}$ with mean minimum and maximum temperatures ranging from $21-30^{\circ} \mathrm{C}$ in the coast (Calabar and Port Harcourt), while it ranges from $29-33^{\circ} \mathrm{C}$ in the interior (Enugu). Rainfall is bimodal and decreases from over $3000 \mathrm{~mm}$ in Calabar to $1,700 \mathrm{~mm}$ in Abakiliki. The vegetation stretches from mangrove swamp in the coast through rainforest to derived savannah in the interior [9].

\subsection{Sampling Technique.}

Two (2) local government areas from each of the three (3) states were randomly selected. Abia consisted Umuahia and Bende: Akwa-Ibom is Obot-Akara and Ikot-Ekpene and Enugu is Udi and Ezeagu Local Government Areas respectively. A structured questionnaire was administered while oral interview complimented the questionnaire. Fifty (50) farmers who had contact with extension agents in the two (2) LGAs of each state were sampled systematically to give a total number of one hundred and fifty (150) farmers. One hundred and thirty five (135) questionnaires which represented ninety percent (90\%) were retrieved. Important information on socio- economic characteristics of the farmers in relation to storage was elicited from the respondents. Data collected were subjected to descriptive statistics like percentage, mean scores, frequency, bar and pie chart.

\section{Results And Discussion}

\subsection{Socio-economic characteristics distribution of Monodora myristica.}

The results of socio-economic analysis of the respondents include sex, age, marital status, family size, level of education and occupation is shown in Table (1). The results showed that the respondents were predominantly males in the study area. This is evident as $60 \%$ were males relative to $40 \%$ females. The farmers between the ages of 41- 70 years were actively involved in the farming and use of M. myristica. Specifically, the ages 61-70 were the highest proportion with $34 \%$ followed by $41-50$ (33\%). The greatest percentage of M. myristica users are predominately married (88\%) within the study area, relative to singles (27\%), widows (11\%) and widowers $(9 \%)$. The family size of majority of respondents have been shown to be in the range of 5-7 $(34.8 \%)$ and $0-4(31 \%)$, followed by $8-10(22.9 \%)$. The results also show that the highest level of education attained by majority of respondents is secondary education (37\%), while primary and tertiary education is $31 \%$ and $20 \%$ respectively. Greater percentages of respondents are farmers. This is shown in the results as $49.6 \%$ relative to civil service $(25 \%)$ and traders $(13 \%)$.

The results show in (Fig.1), showed that $95.3 \%$ of respondents store M. myristica but only $3.70 \%$ of respondents do not store M. myristica. Amidst the various methods of storage the majority of respondents use baskets in storage. This is proved by $59.3 \%$ respondent as against $14.8 \%, 14.7 \%$ and $11.9 \%$ respectively for plastic containers, claypot and calabash. Figure (2) also showed that M. myristica is stored mostly from 10-18 months $(37.0 \%)$ and $36.5 \%$ for $1-3$ months. M. myristica has been shown to germinate after storage. This is evident as $74 \%$ of respondents (Fig 3) from the study area believed as against $26 \%$ that said M. myristica do not germinate after storage. According to the results (Fig 4) 59.3\% of respondents do not use preservatives as against $40.7 \%$ who uses preservatives in M. myristica storage. More than half of the respondents (66.7\%) need government assistance in the storage of $M$. myristica, contrary to $33.3 \%$ respondent who reported that there is no need for government assistance in the storage of $M$. myristica.

Dried pepper (65.9\%) is found to be the most preferred and effective preservative used in preserving $M$. myristica seeds as observed in Figure (5) to compare with the poor acceptance of synthetic pesticides (11.1\%), Ashes $(6.67 \%)$ and Neem leaves powder $(16.3 \%)$. Sun drying $(54.8 \%)$ is generally accepted as the most functional method of seed treatment or preservatives. The results proved that smoking $(25.1 \%)$, use of pesticides $(8.21 \%)$ and pepper (11.9\%) are poorly practiced (Fig.6 ).The results from the study area revealed that pest infestation (54\%) is one of the major problems encountered in storage, followed by lack of chemicals (23\%) and Fungi infestation (15.6\%) (Fig.7).

TABLE 1. Distribution of respondent according to socio-economic characteristics.

$\begin{array}{llll}\text { Variables } & \text { Range } & \text { Freqency } & \text { Percentage } \\ \text { Sex } & \text { Male } & 81 & 60 \\ & \text { Female } & 54 & 40 \\ \text { Age } & \text { Total } & 135 & 100 \\ & 31-40 & 16 & 11.85 \\ & 41-50 & 33 & 24.44 \\ & 51-60 & 31 & 22.96 \\ & 61-70 & 46 & 34.07 \\ & 70 \text { and above } & 09 & 6.68\end{array}$




$\begin{array}{llll} & \text { Total } & 135 & 100 \\ \text { Marital status } & \text { Single } & 27 & 20.00 \\ & \text { Married } & 88 & 65.18 \\ & \text { Widow } & 09 & 6.67 \\ & \text { Widower } & 11 & 8.15 \\ \text { Family size } & \text { Total } & 135 & 100 \\ & 0-4 & 42 & 31.11 \\ & 5-7 & 47 & 34.81 \\ & 8-10 & 31 & 22.96 \\ \text { Level } & 10 \text { and above } & 15 & 11.11 \\ \text { Education } & \text { Total } & 135 & 100 \\ & \text { No formal education } & 15 & 11.11 \\ & \text { Primary } & 43 & 31.85 \\ & \text { Secondary } & 50 & 37.04 \\ \text { ccupation } & \text { Tertiary education } & 27 & 20.00 \\ & \text { Total } & 135 & 100 \\ & \text { Farming } & 67 & 49.63 \\ & \text { Trading } & 18 & 13.33 \\ & \text { Civil service } & 35 & 25.93 \\ & \text { Others } & 15 & 11.11 \\ & \text { Total } & 135 & 100\end{array}$

Source: Field survey, 2011

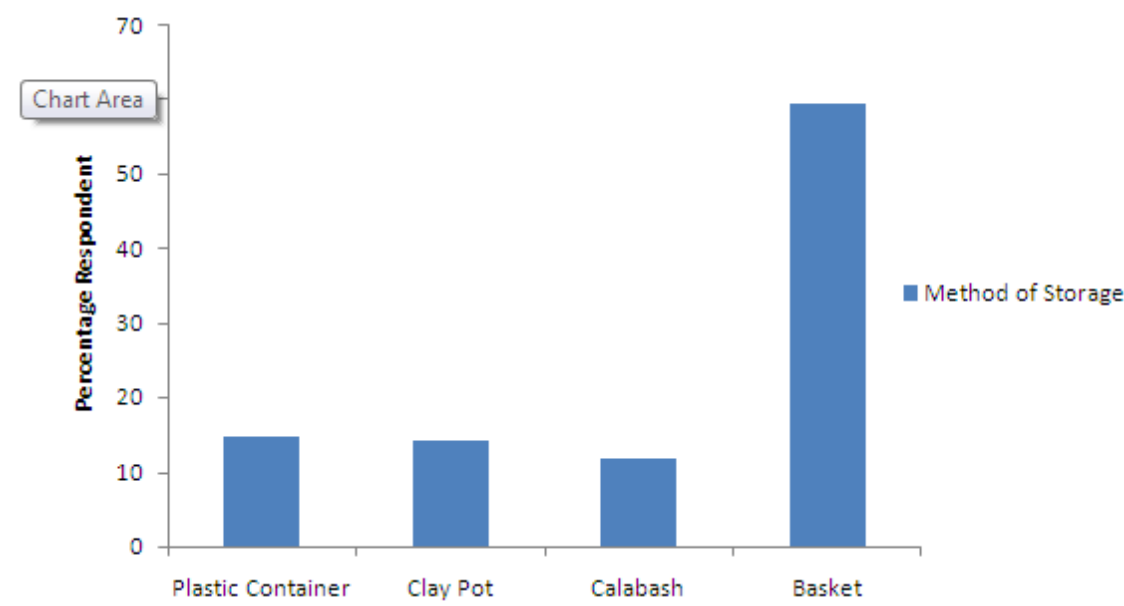

FIGURE 4.1: Distribution according to method of storage of monodora.

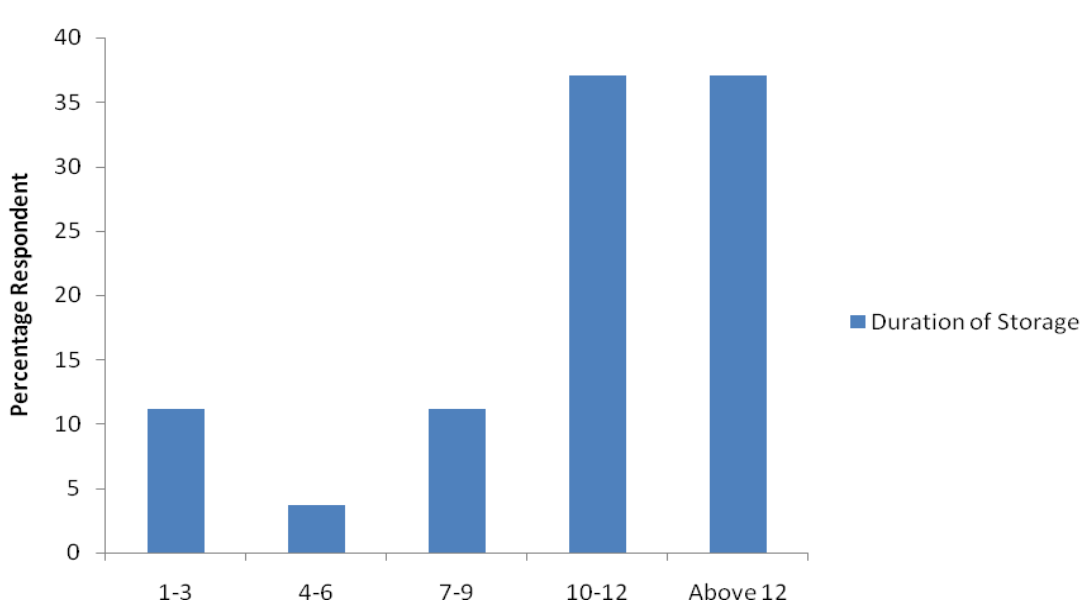

FIGURE 4 .2: Distribution according to duration of storage. 


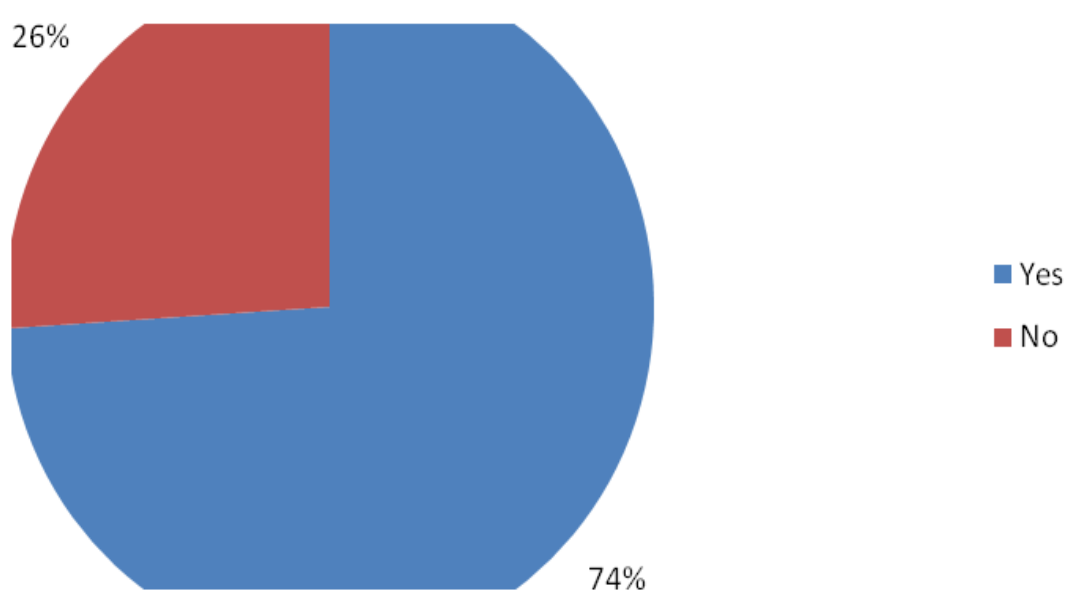

FIGURE 4 .3. Distribution according to germination after storage

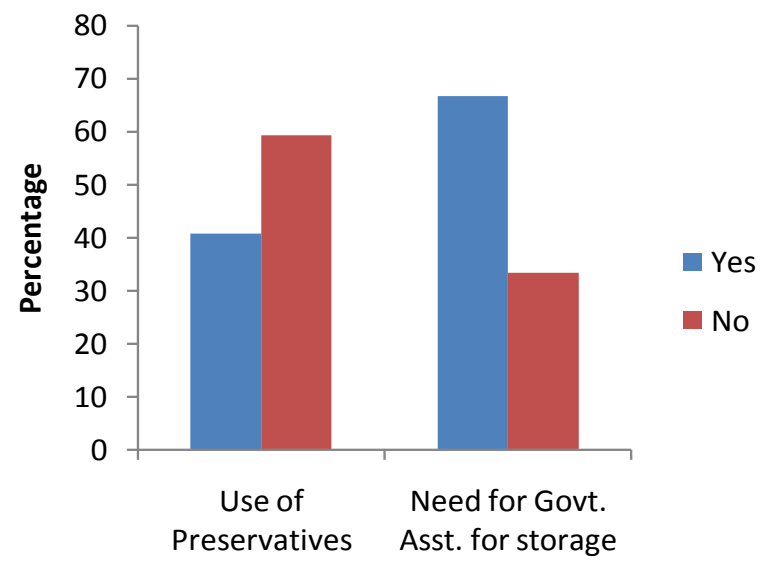

FIGURE 4.4: Distribution according to use of preservatives and need for government assistance for storage.

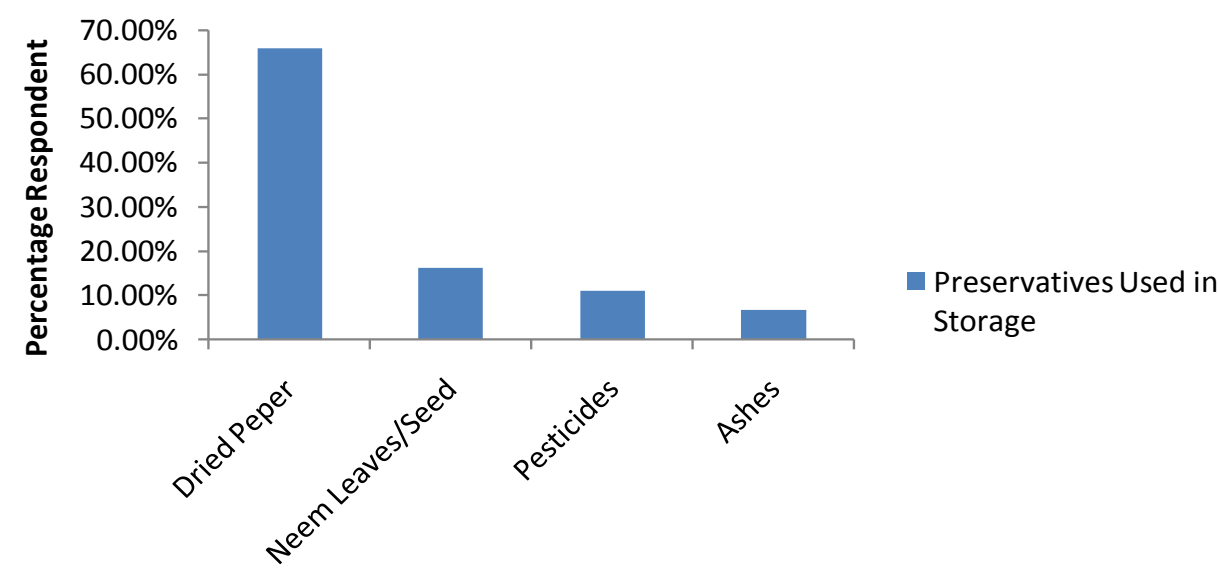

FIGURE. 4.5: Distribution according to preservatives used in storage 


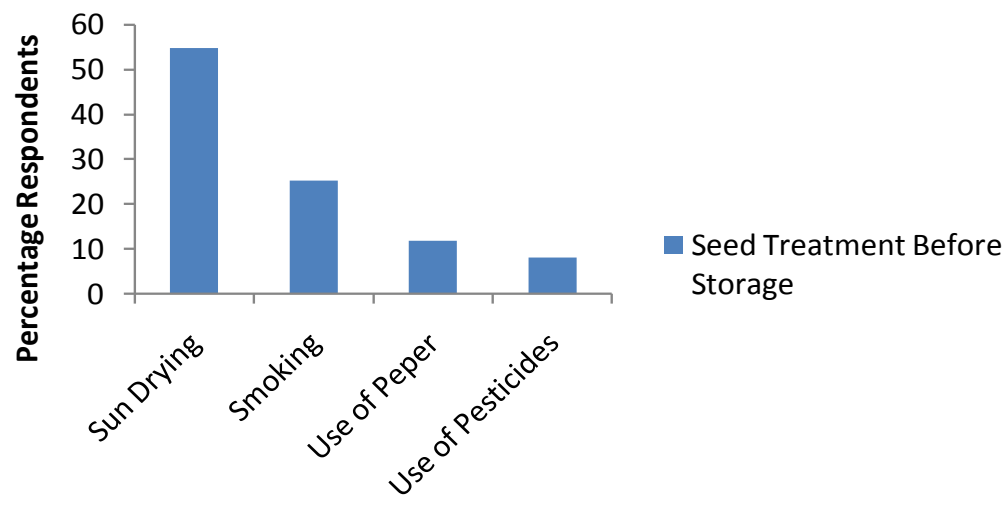

FIGURE.4.6: Distribution according to seed treatment before storage

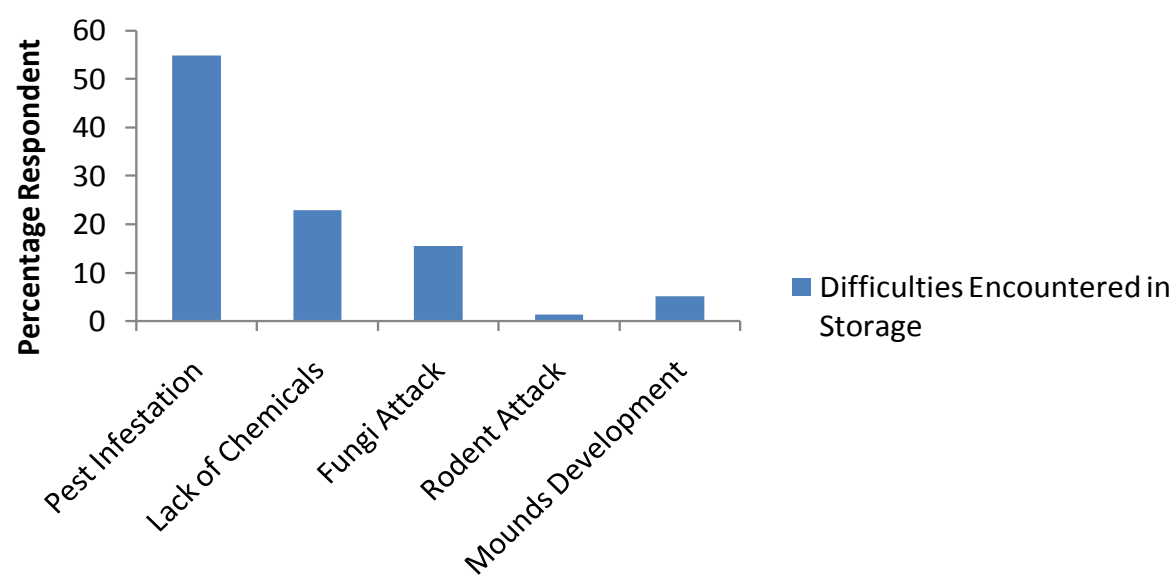

FIGURE 4.7: Distribution according to difficulties encountered in storage.

\section{Discussion}

The Socio-economic characteristics distribution of M. myristica collection/gathering in Southeastern Nigeria is mostly done by male (60\%). This could be attributed to the nature of the farming which is mainly in the wild in combination with other forest species including teck (Tectona species or Baobab). This disagrees with the findings of [10] observed women as major stakeholders in the provision of food. According to the results 61-70 years (34.1\%) of age of the respondents were actively involved in the farming Monodora seeds. This tend to disagree with [11] and [12] which reported that Nigerian farmers are with the age bracket of 4060years, and agrees with [13] who stated that small-scale farmers are 50 years and above. Although experience in farming is very important and it depends on years of farming, yet average young farmers are needed on farms because agricultural production is energy demanding especially collection gathering of Monodora fruits. Monodora users are mainly married (65.3\%), this shows how important marriage institution is in Africa and signifies the possibility of more availability of family labour for farming activities. It also showed the importance of spice as source of food security to individual household. The results (Table 1) showed that $89 \%$ respondents had formal education. [14] and [15] viewed formal education as means of facilitating farmers use of written information sources and increasing their knowledge and comprehension of new farm practices and [16] stated that formal education also predisposes them to adopt improve farm practices. This is also in line with [17] who reported that ability and readiness with which a particular producer accepts an innovation depends on his educational background.

The results from Table (2) shows respondent attitude to storage methods. It indicated that the study area accepts traditional methods storage. This is in line with [18] and [19] which reported that traditional methods of storage have been considered as being highly effective. Good storage systems \methods affect seed germination after storage as investigated by $74 \%$ of respondents. About $59.6 \%$ of the farmers did not use 
preservatives in storing Monodora seeds, this could result to poor storage which was reported to cause up to $10 \%$ loss in seed quality in the Tropics [20]. Insect pest infestation (54\%) is one of the major problems encountered by the farmers. This agrees with [21] which reported that seed storage problems are partly responsible for farmers' failure to save seeds of non-traditional crops. Government assistance in Africa is a recurrent problem which is more acute among the poor farmers, hence $66.7 \%$ of the respondents have solicited for government assistance. This problem should therefore be addressed as seed security is essential in ensuring increased use of agro- biodiversity which would in turn expand the options, opportunities and remains available at the rural grassroots level to improve nutrition and health, safeguard the household economic security and enhance sustainable agriculture.

\section{Conclusion}

The results show that men of about 61-70 years were actively involved in gathering/ collection of $M$. myristica seeds in the study area. $88.9 \%$ of the respondents have knowledge and use $M$. myristica as the need arises. Most respondents stated that good storage systems affect seed germination after storage. Insect pest is one of the major problems encountered by the farmers. Government assistance in Africa is a recurrent problems which is more acute among the poor farmer enhance $66.7 \%$ respondents have solicited for government assistance to improve seed storage for planting.

\section{References}

[1]. M.D. Louise (2002). Spices, Exotic Flavours and Medicines. Biomedical Library. UCLA. p. 1.

[2]. V. S. Govindarajan, (1985). CRC Critical Reviews in Food Science and Nutrition .22, 109-176.

[3]. A. Brown, (2004). Export development of essential oils and spices by cambodia. The International Trade Centre, Geneva [SSA \# 2001-468] and the Ministry of Commerce, Kingdom of Cambodia. p. 100

[4]. D. M. Warren, L. J. Slikkerveer and S.O. Titilola (Eds). (1989). Indigenous Knowledge Systems; Implications for Agriculture and International Development. Studies in Technology and Social Change No. 11. Ames, Iowa: Technology and Social Change Program, Iowa State University.

[5]. G. M Flavier, D.M. Warren, L.J. Slikkerveer and D. Brokensha (1995). 'The regional program for the promotion of indigenous knowledge in Asia', pp. 479-487. The cultural dimension of development: Indigenous knowledge systems. London:

[6]. D. M Warren, (1991). Using Indigenous Knowledge in Agricultural Development; World Bank Discussion Paper No.127. Washington, D.C.: The World Bank.

[7]. B. Rajasekaran, (1990). "Economics of Irrigated Rice Production in Mali." A Study Report, Sahelian Agriculture Division, Washington, D.C.: The World Bank.

[8]. FDALR (Federal Department of Agricultural Land resources), (1985). The Reconnaissance soil. Survey of Imo State (2.25,00).Soil Report pp. 133

[9]. FDALR (Federal Department of Agriculture Land Resources), (1990). The reconnaissance soil survey of Nigeria. Soil Report Vol. 5 FDALR, Kaduna, p. 377

[10]. C., I Aniedu, C.T Nwachukwu,. Uwakah and R.I.A. Unamma (2007). Gender Factors Influencing Adoption of Yam Minisett Techniques by Farmers in South Eastern Nigeria. Implication of Sustainable Yam Production. Journal of Agriculture and Social Research Vol. 7 No.

[11]. E. Ekong, (2003). An Introduction to Sociology. Jumak Push LTD. Ibadan. Pp. 4-5.

[12]. O. Solomon. (1994). Gender Analysis of Oil- Palm Production and Processing in Okiti- pupu Area. Pp 3-5.

[13]. C., I Aniedu,. C.T Nwachukwu,. Uwakah and R.I.A. Unamma (2007). Gender Factors Influencing Adoption of Yam Minisett Techniques by Farmers in South Eastern Nigeria. Implication of Sustainable Yam Production. Journal of Agriculture and Social Research Vol. 7 No.

[14]. C. C Asiabaka, (2002). Agricultural Extension: A Handbook for Dev. Pract. Molsy Fem United Serv. Pp 165-180.

[15]. H. Abubukar, (2000). Economics Analysis of Egg Production in Birinin- Gwari, Jama and Igbai L.g.A of Kaduna State. Unpublished M.Sc Dissertation, Dept. of AEC and Rural Socio. ABU. Zaria, Nigeria.

[16]. K. A Oluyole, (2005). Evaluation of the Economics of Post-Harvest Processing of Cocoa in Cross- River State, Nigeria. Journal of Agriculture, Forestry and Social Science Vol. 3 (2) 58-64.

[17]. H. Abubukar, (2000). Economics Analysis of Egg Production in Birinin- Gwari, Jama and Igbai L.g.A of Kaduna State. Unpublished M.Sc Dissertation, Dept. of AEC and Rural Socio. ABU. Zaria, Nigeria.

[18]. A. T Modi , (2004). Short term preservation of maize landrace Land race a large white pig with ears pitched forwards and top edge level with top line of snout. There are many ethnic varieties originated in Denmark. Seed and taro taro: see arum. Taro Herbaceous plant (Colocasia esculenta) of the arum family, probably native to Southeast Asia and taken to the Pacific islands. propagules using indigenous storage methods. South African Journal of Botany, 70(1): 16-23

[19]. P. A. Pats, (1985). Survey on Maize and Potatoes Storage in Kenya with Particular Reference to Post- Harvest Losses Caused by Insect. Pp 10-15.

[20]. P. W Wambugu, P.W. Mathenge, E.O. Auma, and H.A. Rheenen (2009) Efficacy of traditional Maize (Zea mays L.) seed storage methods in Western Kenya. African Journal of Food, Agriculture, Nutrition and Development.

[21]. J. C. Delouche, (1982). Seed Quality Guidelines for The Small Farmer. In: Improved Seed for the Farmers. Conference Proceedings CIAT (Centre International De Agricultura Tropical. Uk pp 26-29. 